\title{
Mission Book Game: Enhancing Fifth-Grade Students’ Learning Motivation on Thematic Learning
}

\author{
Dewa Ayu Made Candra Dwi Evayani ${ }^{1 *}$, I Nyoman Jampel ${ }^{2}$, I Wayan Widiana ${ }^{3}$ iD \\ 1,2,3 Universitas Pendidikan Ganesha, Singaraja, Indonesia \\ *Corresponding author: ayucandra2097@gmail.com
}

\begin{abstract}
Abstrak
Minimnya penggunaan media pembelajaran dalam proses pembelajaran menyebabkan siswa sulit dalam memahami materi. Penelitian ini bertujuan untuk menghasilkan media pembelajaran yang mampu meningkatkan motivasi dan keaktifan siswa dalam proses pembelajaran. Pengembangan media dalam penelitian ini berpedoman pada prosedur model ADDIE yang terdiri dari beberapa tahapan, yaitu analisis (analyze), desain (design), pengembangan (development), implementasi dan evaluasi (evaluate). Subjek yang terdapat dalam penelitian pengembangan ini adalah media game mission book untuk meningkatkan motivasi belajar siswa kelas $V$ sedangkan objek dalam penelitian ini adalah validitas dan efektivitas media game mission book yang dikembangkan. Metode penelitian pengembangan ini adalah metode analisis kualitatif dan kuantitatif. Pengumpulan data yang digunakan yaitu metode kuesioner degan instrument pengumpulan data berupa rating scale dengan pemberian instrument penilaian kepada 4 orang ahli yaitu, 2 orang ahli materi, 2 orang ahli media, 2 orang respon praktisi dan 12 orang siswa. Data dianalisis dengan melakukan uji validitas dan uji reabilitas media game mission book berdasarkan data dari para ahli, respon praktisi dan siswa. Data yang diperoleh dihitung dengan menggunakan rumus mean untuk mengetahui rata-rata validitas media. Rata-rata skor validitas media game mission book dari segi ahli materi sebesar 4,8 dengan kriteria sangat valid, dari segi ahli media sebesar 4,4 dengan kriteria sangat valid, dari segi respon praktisi sebesar 4,7 dengan kriteria sangat valid dan dari segi respon siswa sebesar 4,9 dengan kriteria sangat valid. Teknik analisis data motivasi yang digunakan adalah teknik analisis data statistik deskriptif kuantitatif berupa uji prasyarat dan uji-t. Hasil penelitian uji hipotesis menunjukkan nilai signifikansi sebesar 0,033 yang berarti 0,033<0,05, sehingga dapat disimpulkan terdapat pengaruh media game mission book untuk meningkatkan motivasi belajar tematik siswa kelas $V$.
\end{abstract}

Kata kunci: Media, Game Mission Book, Motivasi Belajar

\begin{abstract}
The lack of use of learning media in the learning process causes students to find it difficult to understand the material. This study aims to produce learning media that can increase students' motivation and activeness in the learning process. Media development in this study is guided by the ADDIE model procedure which consists of several stages, namely analysis (analyze), design (design), development (development), implementation, and evaluation (evaluate). The subject in this development research is the mission book game media to increase the learning motivation of fifth-grade students while the object in this research is the validity and effectiveness of the mission book game media developed. This development research method is a qualitative and quantitative analysis method. The data collection used is a questionnaire method with data collection instruments in the form of a rating scale by giving an assessment instrument to 4 experts, namely, 2 material experts, 2 media experts, 2 practitioner responses, and 12 students. The data were analyzed by testing the validity and reliability test of the mission book game media based on data from experts, practitioners, and students' responses. The data obtained is calculated using the mean formula to determine the average validity of the media. The average validity score of the mission book media game in terms of material experts is 4.8 with very valid criteria, in terms of media experts it is 4.4 with very valid criteria, in terms of practitioner responses it is 4.7 with very valid criteria and in terms of student response of 4.9 with very valid criteria. The motivational data analysis technique used is descriptive quantitative statistical data analysis techniques in the form of prerequisite tests and t-tests. The results of the hypothesis test showed a significance value of 0.033 which means $0.033<0.05$, so it can be concluded that there is an effect of the the mission book game media to increase the thematic learning motivation of fifth-grade students.
\end{abstract}

Keywords: Media, Mission Book Game, Learning Motivation

$\begin{array}{ll}\text { History: } & \text { Publisher: Undiksha Press } \\ \text { Received : September 19, } 2021 & \text { Licensed: This work is licensed under } \\ \text { Revised : September 20, } 2021 & \text { a Creative Commons Attribution 3.0 License } \\ \text { Accepted : October 04, 2021 } & \text { CC (i) (O) } \\ \text { Published : October 25, 2021 } & \end{array}$

\section{INTRODUCTION}

The current Covid-19 pandemic that is being faced by the world and of course greatly affects various fields of people's lives, especially the world of education today (Wu et al., 
2019; Zhang et al., 2020). Given the Covid-19 Pandemic, which has caused learning that should have been carried out face-to-face to become online learning (Alrefaie et al., 2020; Bozkurt et al., 2020). Online learning is carried out according to the abilities of each school, online learning activities can be carried out using digital technology such as: google classroom, RumahBelajar, zoom, video conference, live chat, and distributed with various content such as Word, PDF, Excel files, audio, video as well as student assessments using quizzes and rubric-based assessments of the submitted assignments (Pokhrel \& Chhetri, 2021). Various digital technologies have supported the task of teachers as educators, with technological sophistication, teachers must be able to design learning during this pandemic by being able to adapt creatively in the online world and students can achieve learning outcomes (Quay et al., 2020). During the pandemic, the suspension of face-to-face learning continues to drag on. The suspension of face-to-face teaching in schools during the COVID19 Pandemic has raised concerns about the consequences for student learning and caused various problems (Engzell et al., 2021).

The most visible problem during the Covid-19 pandemic in the education sector was how to make the remote teaching and learning process interesting so that it could increase students' learning motivation considering that elementary school students were still in the concrete operational stage, considering that when teacher learning activities only relied on content. Materials and questions in the teacher and student handbooks (Astra et al., 2020; Rehusisma et al., 2017). So, in this case students in the learning process need concrete objects and this is a problem during the online learning process. The next problem is expertise in the use of technology from both educators and students (Handarini, 2020). This problem is supported by interviews with elementary school teachers who obtained the results of interviews with the teacher's lack of understanding of the development of learning media, as well as the results of observations of learning media so that what is used is still visual such as only pictures, the material listed in student books is still shallow. and need to be developed, and the results of recording student learning outcomes documents obtained data that learning activities do not increase student learning motivation.

The existence of a gap between the fact that technology supports online learning and does not materialize with the teacher's understanding of the development of learning media and the lack of student learning motivation, of course, should not be ignored, it needs to be followed up with the development of learning media. One of the media that can support distance learning activities and increase student learning motivation is the Game Mission Book learning media, which is a book that contains certain missions or goals that are packaged in the form of games that must be achieved by students in certain subject matter or sub-subjects. Media Game Mission Book is integrated with 24 learning activities according to Anderson and Krathwohl's Revised Bloom Taxonomy. Through this learning media, it will provide learning stimulation for students through the missions in the book that must be completed. Students, especially at the elementary school level, when given learning without media will certainly reduce the enthusiasm and stimulation of learning so that students' concentration and attention tend not to be focused on the material. However, when given media, especially the Mission Book Game, learning becomes more fun which indirectly brings students to an increase in learning focus that is oriented towards challenging missions to be carried out in the Mission Book Game media.

Several relevant previous studies have examined the development of media that is integrated with games. The first study showed that there was an increase in students' motivation and interest in learning by using game-based media, namely Game-Based Learning (Redy et al., 2020) Furthermore, the second study also showed similar results. The development of the Mission Book Game could increase students' reading interest in language learning. Indonesia High-Class Elementary School (Rahmat et al., 2017). Then another study 
states that the development of media that is integrated with games, namely Game-Based Learning based on a scientific approach can improve students' understanding abilities and learning motivation (Maulidina et al., 2018). In addition, games have several important roles to be able to improve the development of the human brain, namely in concentration and training to solve problems correctly and quickly, because in games some various conflicts or problems require us to solve them quickly and precisely (Rahmawati et al., 2020). Therefore, the update of this research is to develop the Game Mission Book media, which is a media that is integrated with 24 learning activities of Anderson \& Krathwohl Revised Bloom Taxonomy which are packaged in the form of mission and challenge games. This study aims to create a mission book game media and to be able to obtain an increase in the learning motivation of fifth-grade students in SD Gugus II, Susut District.

\section{METHODS}

This research is a type of development research (Sugiyono, 2014). The product developed in this research is a Game Mission Book learning media. The development is carried out using the ADDIE development model which consists of stages (Analyze, Design, Development, Implementation, Evaluation). The selection of this model is carried out on a systematic basis and is suitable to be used to overcome learning problems related to learning resources and adapted to the needs and characteristics of students (Tegeh et al., 2014). The stages of development are presented in Picture 1.

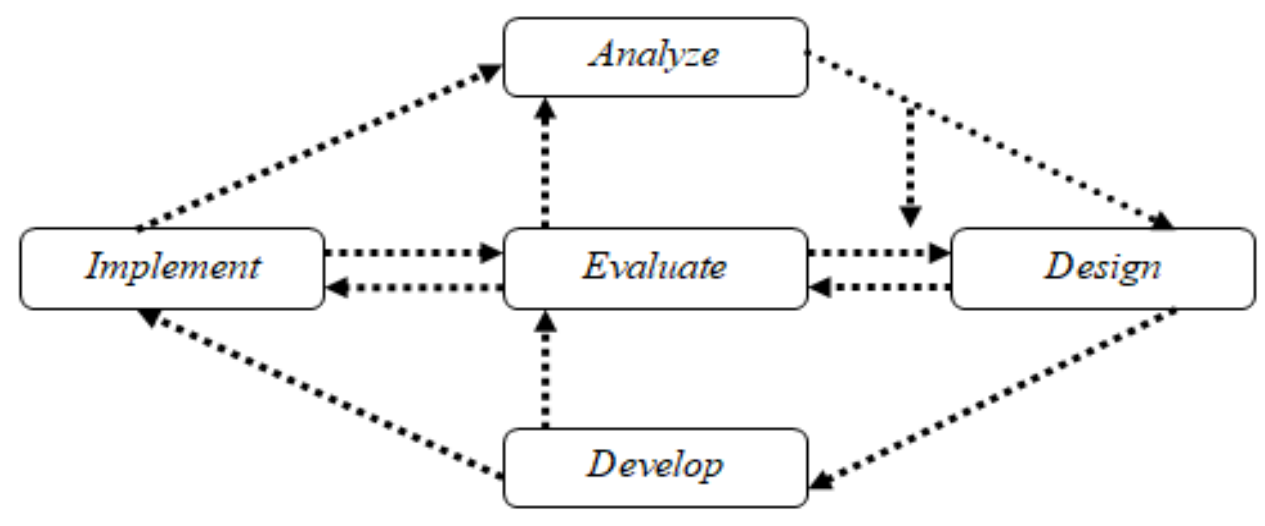

Picture 1. Stages Model ADDIE (Tegeh et al., 2014).

The subject in this development is the Game Mission Book media to increase students' learning motivation. While the object of this study is the validity and effectiveness of the learning media developed, namely the Game Mission Book media to increase the learning motivation of class $\mathrm{V}$ students. The parties involved in the process of testing the validity of the developed media include 4 experts, namely 2 material experts, 2 media experts, 2 practitioner responses, and 12 students as product trial respondents who were divided into small groups and individuals. Collecting data using an instrument in the form of a questionnaire sheet. Questionnaire sheets were used to measure and assess the validity of the product developed from the results of reviews conducted by material and assessment experts, media experts, practitioners, and student responses during small group trials. The instrument grid is presented in Table 1. 
Table 1. Expert Validation Instrument Grid

\begin{tabular}{|c|c|c|}
\hline Aspect & Indicator & References \\
\hline \multicolumn{3}{|c|}{ a. Material expert } \\
\hline $\begin{array}{l}\text { Use of } \\
\text { Language }\end{array}$ & a. Quality of Language use & $\begin{array}{l}\text { (Kusumawardhana, } \\
\text { 2014) }\end{array}$ \\
\hline $\begin{array}{l}\text { Contents of } \\
\text { questions }\end{array}$ & $\begin{array}{l}\text { a. Conformity with the achievement of students' } \\
\text { cognitive level }\end{array}$ & \\
\hline & $\begin{array}{l}\text { b. The relevance of practice questions to basic } \\
\text { competencies }\end{array}$ & \\
\hline & c. Relevance of practice questions to indicators & \\
\hline & $\begin{array}{l}\mathrm{d} \text {. The relevance of the question material to the } \\
\text { level of student development }\end{array}$ & \\
\hline & $\begin{array}{l}\text { e. The relevance of practice questions to the } \\
\text { material in the lesson content }\end{array}$ & \\
\hline \multicolumn{3}{|c|}{ f. Media expert } \\
\hline \multirow[t]{2}{*}{ Cover } & a. Complete media identity & (Yaumi, 2018) \\
\hline & $\begin{array}{l}\text { b. Appropriateness of the type of font used } \\
\text { c. Image suitability on the cover }\end{array}$ & \\
\hline \multirow[t]{4}{*}{ Format } & $\begin{array}{l}\text { a. Color compatibility of text and images on the } \\
\text { media game mission book }\end{array}$ & \\
\hline & $\begin{array}{l}\text { b. The compatibility of the use of fonts and font } \\
\text { sizes }\end{array}$ & \\
\hline & $\begin{array}{l}\text { c. The suitability of the position of the image on } \\
\text { the media }\end{array}$ & \\
\hline & d. Images are easy to understand & \\
\hline \multirow[t]{3}{*}{ Language } & a. Ease of understanding the language used & \\
\hline & b. The effectiveness of the sentences used & \\
\hline & c. Standard language used & \\
\hline \multirow[t]{2}{*}{ Practical } & a. Clear instructions for use & \\
\hline & b. Easy to use mission book game media & \\
\hline \multicolumn{3}{|c|}{ g.Practitioner } \\
\hline Media & a. Cover view & (Muyaroah \& \\
\hline \multirow[t]{3}{*}{ Quality } & b. Color combinations & Fajartia, 2017; \\
\hline & c. Image placement & Noviar, 2016) \\
\hline & d. Fonts and sizes & \\
\hline Media & a. Conformity with competence & \\
\hline \multirow[t]{2}{*}{ Content } & b. Compliance with indicators & \\
\hline & c. Compatibility with material & \\
\hline \multirow{3}{*}{$\begin{array}{l}\text { Language } \\
\text { Usage }\end{array}$} & a. Conformity to the level of development of & \\
\hline & students & \\
\hline & b. Easy to understand & \\
\hline \multicolumn{3}{|c|}{ h.Student response } \\
\hline \multirow[t]{2}{*}{ Contents } & a. Easy to understand & (Muyaroah \& \\
\hline & b. Compatibility with material & Fajartia, 2017; \\
\hline Material & a. The attractiveness of the media display & Noviar, 2016) \\
\hline Serving & b. Ease of use of media & \\
\hline & c. Use of letters and sizes & \\
\hline
\end{tabular}


Data analysis techniques used in the development of this media include quantitative descriptive analysis and qualitative descriptive analysis. Qualitative descriptive statistical analysis methods in development research are related to processing words or sentences in the form of responses, criticisms, suggestions, input, and reviews of learning experts resulting from an object of research (Agung, 2014; Sugiyono, 2014).

\section{RESULTS AND DISCUSSION}

\section{Results}

Analyze Stage. At this stage, several stages were carried out, namely curriculum analysis, needs analysis, student characteristics analysis, and media analysis. At the curriculum analysis stage, it is carried out by analyzing Core Competencies, Basic Competencies, and indicators of achievement of learning objectives contained in the teacher's books and student books which are summarized in Table 2.

Table 2. Basic Competencies and Mission Book Media Development Indicators

\begin{tabular}{|c|c|c|}
\hline \multicolumn{2}{|r|}{ Basic Competencies } & Indicator \\
\hline & $\begin{array}{l}\text { Apply the concept of heat } \\
\text { transfer in daily life. }\end{array}$ & $\begin{array}{l}\text { 3.6.1 Name the objects that are included as sources of } \\
\text { heat energy. } \\
\text { 3.6.2 Match the statement which is a source of heat } \\
\text { energy. } \\
\text { 3.6.4 Define heat energy sources. } \\
\text { 3.6.5 Explain the meaning of heat energy sources. } \\
\text { 3.6.6. Give an example of the heat transfer process in } \\
\text { everyday life. } \\
\text { 3.6.7 Describe the process of heat transfer } \\
\text { 3.6.8 Describe the benefits of heat transfer } \\
\text { 3.6.9 Classifying objects that can conduct heat quickly } \\
\text { and objects that can conduct heat slowly. } \\
\text { 3.6.10 Distinguish between temperature and heat } \\
\text { 3.6.11 Concepting the process of movement of objects } \\
\text { 3.6.12 Determining objects that can conduct heat } \\
\text { conduction, convection and radiation } \\
\text { 3.6.13 Proving heat transfer by conduction, convection } \\
\text { and radiation. }\end{array}$ \\
\hline 4.6 & $\begin{array}{l}\text { Report observations about } \\
\text { heat transfer. }\end{array}$ & $\begin{array}{l}\text { 4.6.1 Concluding observations regarding heat transfer } \\
\text { 4.6.2 Making observations of the heat transfer process } \\
\text { by conduction, convection and radiation. }\end{array}$ \\
\hline & $\begin{array}{l}\text { Summarizing explanatory } \\
\text { text (explanation) from } \\
\text { print or electronic media. }\end{array}$ & $\begin{array}{l}\text { 3.3.1 Making conclusions from reading } \\
\text { 3.3.2 Make a summary of the short reading text }\end{array}$ \\
\hline
\end{tabular}

Then at the stage of needs analysis is carried out to determine the needs of teachers and students in the learning process. The needs analysis was carried out through observations and interviews with classroom teachers and students about the needs of elementary school students in thematic learning at SD Gugus II, Susut District, as well as through group 5 observations through the WhatsApp application media to find out about student learning activities in class and student characteristics. The next stage is media analysis, to determine the quality of learning media that is good and appropriate for the learning process. In developing the mission book media game media to increase students' thematic learning 
motivation there are several criteria used including media design, the content of questions, media presentation, quality of media, question material, use of language, and ease of use of media.

Design Stage. The learning media designed at this stage are the mission book game media to increase students' learning motivation, the media developed in the form of books packaged in the form of mission games. The media game mission book consists of a cover, table of contents, instructions for use, there are 3 missions, each mission has 6 levels. Mission 1, on Temperature and Heat. Mission 2, about Heat Transfer. Mission 3, Effect of Heat on Life. Every 1 level there are 4 practice questions, the pictures on the media are made as attractive as possible so that students are excited to take the test, a list of record achievements, and certificates. The media game mission book is printed using A4 size paper. Some of the results of the mission book game media design are presented in Picture 2 and Picture 3.

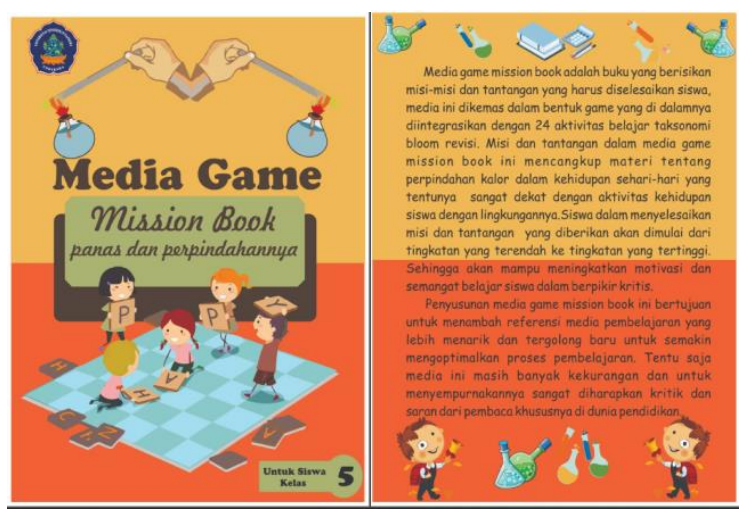

Picture 2. Cover

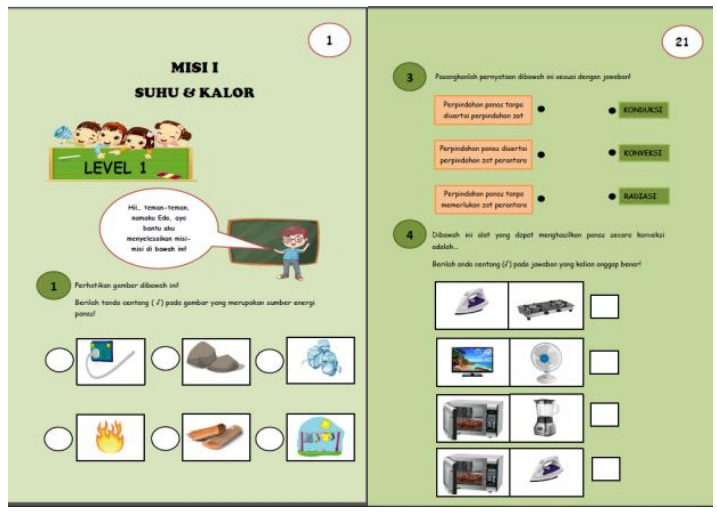

Picture 3. Content

Development Stage. At the development stage, a series of mission book game media development processes were carried out. development is done through testing the validity of the media that has been designed previously. The validity test was carried out to get comments, suggestions, and input from experts and practitioners' responses regarding the products that have been developed. The comments and inputs are presented in Table 3.

Table 3. Comments, Suggestions and Feedback

\begin{tabular}{cl}
\hline No. & \multicolumn{1}{c}{ Comments, Suggestions and Feedback } \\
\hline 1 & Fix the question editor \\
2 & Fix Game instructions don't confuse students \\
3 & Image layout adjusted to make it look more attractive \\
4 & The product is well made and attractive \\
\hline
\end{tabular}

Based on comments, suggestions, and input from content experts, media experts, and practitioner responses regarding the development of the mission book game media so that they can make improvements to the media based on comments, suggestions, and input provided by experts and the results of the validity of the media developed based on the results of the evaluation conducted by material experts, media experts, practitioner responses and student responses in small group and individual trials. evaluation data from experts and product test subjects were analyzed descriptively by looking for the average score. The results of the media validity test are presented in Table 4. 
Table 4. Summary of Media Validity Test Results

\begin{tabular}{clcc}
\hline No. & \multicolumn{1}{c}{ Test Subject } & Average Score & Information \\
\hline 1 & Materials/Assessment Expert & 4.8 & Very Valid \\
2 & Learning Media Expert & 4.4 & Very Valid \\
3 & Practitioner Response & 4.7 & Very Valid \\
4 & Student Response (Small Group Test) & 4.9 & Very Valid \\
\hline
\end{tabular}

Based on the results of data analysis obtained from experts regarding the Game Mission Book media for class V students, it is stated that it is very good and very valid. The normality test on the motivation questionnaire was carried out to know that the distribution of data from each variable did not deviate from the characteristics of data that were normally distributed. Test the normality of the distribution of data in the data group using Kolmogorov Smirnov analysis with the SPSS 25.0 for Windows program. Kolmogorov Smirnov's significance value is greater than 0.05 . Thus, all data distributions can be said to be normally distributed. The results of the normality test of data distribution can be seen in Table 5 .

Table 5. Data Distribution Normality Test

\begin{tabular}{|c|c|c|c|c|c|c|c|}
\hline \multicolumn{8}{|c|}{ Tests of Normality } \\
\hline & \multirow[b]{2}{*}{ Kelas } & \multicolumn{3}{|c|}{ Kolmogorov-Smirnov } & \multicolumn{3}{|c|}{ Shapiro-Wilk } \\
\hline & & Statistic & Df & Sig. & Statistic & df & Sig. \\
\hline \multirow[t]{2}{*}{ Hasil } & Eksperimen & 0.156 & 15 & $.200^{*}$ & 0.905 & 15 & 0.115 \\
\hline & Kontrol & 0.157 & 15 & $.200^{*}$ & 0.905 & 15 & 0.115 \\
\hline
\end{tabular}

The homogeneity test of activity variance and learning outcomes was carried out to show that two or more groups of sample data came from those with the same variance. Based on the table of analysis results, it can be seen that the significance value of Based on Mean in each data distribution is greater than 0.05. Thus, it can be concluded that the learning motivation of class $\mathrm{V}$ students has a homogeneous variance. The results of the homogeneity test of the data distribution can be seen in table 2. After the Prestayat Test has been carried out, then the hypothesis test is carried out. Hypothesis testing aims to determine the extent to which the effectiveness of Media Game Mission Book can affect the results of thematic learning motivation of fifth-grade students in SD Cluster II, Susut District. Based on the table of hypothesis test results, the significance value (Sig. (2-tailed)) on the t-test for Equality of Means was 0.033. Furthermore, the significance value is compared with 0.05 . This means $0.033<0.05$ so Ho is rejected and H1 is accepted. So, it can be concluded that there is an effect of the effectiveness of the mission book game media to increase the thematic learning motivation of fifth-grade students in SD Cluster II, Susut District. The results of the Hypothesis Testing the distribution of data can be seen in Table 6.

Table 6. Test the Homogeneity of Students' Learning Motivation Results

\begin{tabular}{|c|c|c|c|c|c|}
\hline \multicolumn{6}{|c|}{ Test of Homogeneity of Variances } \\
\hline & & Levene Statistic & df1 & df2 & Sig. \\
\hline \multirow[t]{4}{*}{ Hasil } & Based on Mean & 1.859 & 1 & 28 & 0.184 \\
\hline & Based on Median & 1.328 & 1 & 28 & 0.259 \\
\hline & $\begin{array}{l}\text { Based on Median and with } \\
\text { adjusted df }\end{array}$ & 1.328 & 1 & 23.061 & 0.261 \\
\hline & Based on trimmed mean & 1.709 & 1 & 28 & 0.202 \\
\hline
\end{tabular}


The next stage is to test the hypothesis, to find out how far the effectiveness of the Media Game Mission Book can affect the results of thematic learning motivation of fifthgrade students in SD Cluster II, Susut District. The results of the calculation of the Independent Samples Test analysis using the SPSS 25.0 for Windows program can be seen in Table 7.

Table 7. Hypothesis Test Results of Students' Learning Motivation

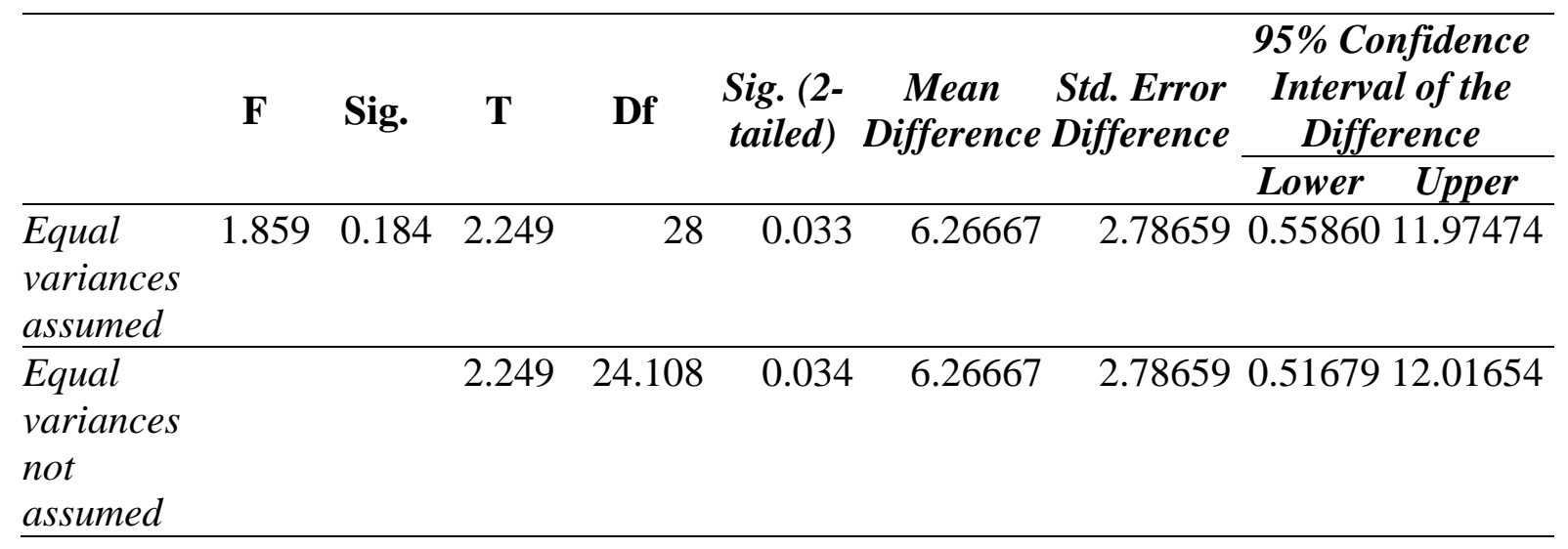

Based on the table of hypothesis test results, the significance value (Sig. (2-tailed)) on the t-test for Equality of Means was 0.033 . Furthermore, the significance value was compared with 0.05 . Which means $0.033<0.05$ so Ho is rejected and H1 is accepted. So, it can be concluded that there is an effect of the effectiveness of the mission book game media to increase the thematic learning motivation of fifth grade students in SD Cluster II, Susut District.

\section{Discussion}

This development research creates a mission book game media that has been declared valid by material experts, media, practitioner responses, and student responses and based on the calculation of the mission book game media effectively increases the learning motivation of elementary school students this is because this media is integrated with 24 Revised Bloom's Taxonomy learning activities Anderson \& Krathwohl. Through this mission book, game media students will be able to construct their knowledge through the missions and challenges contained in the book, these missions and challenges will be able to increase students' motivation and enthusiasm for learning. The mission book media game that has been developed has gone through a series of development stages following the ADDIE model procedure, namely the analysis stage, the design stage, the development stage, the implementation stage, and the evaluation stage. The selection of the ADDIE model was based on the consideration that the ADDIE model was developed systematically based on the theoretical basis of learning design so that it could be used as the basis for developing media with good product quality (Tegeh \& Jampel, 2017; Tegeh et al., 2015). Thus, the development of learning media using the ADDIE model is very appropriate and following the characteristics and needs (Andrajati et al., 2020; Prananda, 2020).

Mission book media games increase students' learning motivation supported by expert opinion, namely, game-based learning is becoming increasingly popular and there is an increase in learning and learning motivation with game-based learning compared to conventional learning (Ennis, 2018). Most studies evaluate positively the effects of games on learning, social interaction, and cultural communication (Zhonggen, 2019). In addition to expert opinion, the results of the study show that games-based learning and/or simulations 
have a positive impact on targeted learning and identify an increase in learning outcomes when integrating games into the learning process: namely cognitive, behavioral, and affective aspects (Vlachopoulos \& Makri, 2017). Educational games have a very high impact on perceptions, motivation, and positive attitudes (Marsa et al., 2021).

The results showed that the use of games in learning can increase the motivation of preschool children. In addition, the effects of games can attract children's attention and can help to improve the skills of preschoolers (Mahazir et al., 2019). The use of educational games has led to a significant increase in student achievement and motivation (Sabirli \& Coklar, 2020). The application of game-based learning (GBL) is seen as having many benefits in helping to improve the quality of the teaching and learning process and has a positive impact on increasing student motivation (Ramli et al., 2020). The results of further research, namely, games that are integrated into learning tools can improve elementary school student learning outcomes obtained through increasing experimental group posttest learning outcomes (Nand et al., 2019). There is a positive effect of game-based learning on students' learning motivation, involvement, and attitudes, which is 84\% (Vankúš, 2021).

The development of the Mission Book Game was in the previous research the game was applied to learning for elementary school students in grade VI SD, while in the development of the Game Mission Book for grade V elementary school students, the subjects in previous research were only on learning Mathematics, while in the Mission Book game the subjects Thematically, in addition to the Game Mission book game, it is included in teaching materials, while previous research is specifically for educational games on computers and learning activities. The implication of the creation of the Mission Book Game is that enthusiasm makes students' learning motivation increase because in the mission book game media there are missions and challenges students will be able to construct their own knowledge, with these missions and challenges will be able to increase students' learning motivation in participating in the learning process. And the mission book game media is able to make the learning process active because basically, elementary school students are theoretically in a concrete operational phase so that when students learn they need the help of objects that are concrete or real to help students more easily understand the material being studied. The limitation of the Mission Book Game media is that it can only be used in thematic learning for fifth-grade elementary school and increases students' learning motivation. Therefore, for further development research, similar development research can be carried out by expanding the subject of development and adding variables other than learning motivation variables.

\section{CONCLUSION}

The mission book game media developed is valid and suitable for use in the learning process. In addition, based on the results of trials that have been carried out, it was found that the Mission Book learning media developed had a positive contribution to increasing students' learning motivation. Basically, elementary school students are theoretically in a concrete operational phase so that when students learn they need the help of objects that are concrete or real to help students more easily understand the material being studied. Mission book game media can be used in the learning process to make the learning process active.

\section{REFERENCES}

Agung, A. A. G. (2014). Metologi Penelitian Pendidikan. Aditya Media Publishing.

Alrefaie, Z., Hassanien, M., \& Al-Hayani, A. (2020). Monitoring Online Learning During COVID-19 Pandemic; Suggested Online Learning Portfolio (COVID-19 OLP). 
MedEdPublish, 9(1), 1-4. https://doi.org/10.15694/mep.2020.000110.1.

Andrajati, N. H., Anis, M. B., \& Mahmudi, A. (2020). Development of online thematic teaching materials based on higher order thinking skills (HOTS) subtheme Wealth of Energy Sources in Indonesia. IJIS Edu: Indonesian Journal of Integrated Science Education, 2(2), 152. https://doi.org/10.29300/ijisedu.v2i2.3427.

Astra, I. M., Raihanati, R., \& Mujayanah, N. (2020). Development of Electronic Module Using Creative Problem-Solving Model Equipped with Hots Problems on The Kinetic Theory of Gases Material. Jurnal Penelitian \& Pengembangan Pendidikan Fisika, 6(2), 181-194. https://doi.org/10.21009/1.06205.

Bozkurt, A., Jung, I., Xiao, J., Vladimirschi, V., Schuwer, R., Egorov, G., Lambert, S., AlFreih, M., Pete, J., Olcott Jr., D., Rodes, V., Aranciaga, I., Bali, M., Alvarez Jr., A., Roberts, J., Pazurek, A., Raffaghelli, J., Panagiotou, N., de Coëtlogon, P., ... Paskevicius, M. (2020). A global outlook to the interruption of education due to COVID-19 Pandemic: Navigating in a time of uncertainty and crisis. Asian Journal of Distance Education, 15(1), 1-126. https://doi.org/10.5281/zenodo.3878572.

Engzell, P., Frey, A., \& Verhagen, M. D. (2021). Learning Loss Due to School Closures During The COVID-19 Pandemic. Proceedings of the National Academy of Sciences of the United States of America, 118(17), 1. https://doi.org/10.1073/PNAS.2022376118.

Ennis, L. (2018). Game-Based Learning : An Instructional Tool Game-Based Learning : An Instructional Tool. Lowa State Unoversity.

Mahazir, I., Ismail, Khadijah, S., Anis, Ismail, M. E., Kamaruzzaman, Ismail, Morazah, \& Nordin, M. (2019). Impact of Games on Motivation, Attention and Skills In Preschool Children. International Journal of Advanced Trends in Computer Science and Engineering, 8(13), 157. https://doi.org/10.30534/ijatcse/2019/3181.32019.

Marsa, S. S., Kuspiyah, H. R., \& Agustina, E. (2021). The Effect of Kahoot! Game in Teaching Reading Comprehension Achievement. JET (Journal of English Teaching), 7(2021), 147. https://doi.org/https://doi.org/10.33541/jet.v7i2.2738.

Muyaroah, S., \& Fajartia, M. (2017). Pengembangan Media Pembelajaran Berbasis Android dengan menggunakan Aplikasi Adobe Flash CS 6 pada Mata Pelajaran Biologi. Innovative Journal of Curriculum and Educational Technology, 6(2), 79-83.

Nand, K., Baghaei, N., Casey, J., Barmada, B., Mehdipour, F., \& Liang, H.-N. (2019). Engaging Children With Educational Content Via Gamification. Smart Learning Environments, 6(1), 15. https://doi.org/10.1186/s40561-019-0085-2.

Noviar, D. (2016). Pengembangan Ensiklopedi Biologi Mobile Berbasis Android Materi Pokok Pteridophyta Dalam Rangka Implementasi Kurikulum 2013. Cakrawala Pendidikan, 35(2). https://doi.org/https://doi.org/10.21831/cp.v15i2.8255.

Pokhrel, S., \& Chhetri, R. (2021). A Literature Review on Impact of COVID-19 Pandemic on Teaching and Learning. Higher Education for the Future, 8(1), 35. https://doi.org/10.1177/2347631120983481.

Prananda, G. (2020). Pengembngan Media Video Pembelajaran Tema 6 Subtema 2 Untuk Siswa Kelas SD Negeri 17 Pasar Masurai 1. Jurnal Dharma PGSD, 1(1), 38-45.

Quay, J., Gray, T., Thomas, G., Allen-Craig, S., Asfeldt, M., Andkjaer, S., Beames, S., Cosgriff, M., Dyment, J., Higgins, P., Ho, S., Leather, M., Mitten, D., Morse, M., Neill, J., North, C., Passy, R., Pedersen-Gurholt, K., Polley, S., ... Foley, D. (2020). What future/s For Outdoor And Environmental Education in a World That Has Contended With COVID-19? Journal of Outdoor and Environmental Education, 29(39), 94. https://doi.org/10.1007/s42322-020-00059-2.

Rahmawati, I., Leksono, I., \& Harwanto. (2020). Pengembangan Game Petualang untuk Pembelajaran Berhitung. Edcomtech Jurnal Kajian Teknologi Pendidikan, 5(1), 14. 
https://doi.org/10.17977/um039v5i12020p011.

Ramli, I. S. M., Maat, S. M., \& Khalid, F. (2020). Game-Based Learning and Student Motivation in Mathematics. International Journal of Academic Research in $\begin{array}{llll}\text { Progressive Education and Development, } 4(2), & 449 .\end{array}$ https://doi.org/10.6007/ijarped/v9-i2/7487.

Rehusisma, L. A., Indriwati, S. E., \& Suarsini, E. (2017). Pengembangan Media Pembelajaran Booklet Dan Video Sebagai Penguatan Karakter Hidup Bersih Dan Sehat. Jurnal Pendidikan: Teori, Penelitian, Dan Pengembangan, 2(9), 1238-1243.

Sabirli, Z. E., \& Coklar, A. N. (2020). The Effect of Educational Digital Games on Education, Motivation and Attitudes of Elementary School Students Against Course Access. World Journal on Educational Technology: Current Issues, 12(3), 175. https://doi.org/10.18844/wjet.v12i3.4993.

Sugiyono. (2014). Metode Penelitian Pendidikan Pendekatan Kuantitatif, Kualitatif, dan $R \& D$. Alfabeta.

Tegeh, I. M., \& Jampel, I. N. (2017). Metode Penelitian Pengembangan. Universitas Pendidikan Ganesha.

Tegeh, M., Pudjawan, K., \& Jampel, N. (2015). Model Penelitian Pengembangan. Graha Ilmu.

Vankúš, P. (2021). Influence Of Game-Based Learning In Mathematics Education On Students' Affective Domain: A Systematic Review. Mathematics Ejournal Comenius University in Bratislava, 9(9), 2. https://doi.org/10.3390/math9090986.

Vlachopoulos, D., \& Makri, A. (2017). The Effect of Games and Simulations on Higher Education: a Systematic Literature Review. In International Journal of Educational Technology in Higher Education (Vol. 14, Issue 1). International Journal of Educational Technology in Higher Education. https://doi.org/10.1186/s41239-0170062-1.

Wu, Y., Chen, C., \& Chan, Y. (2019). The outbreak of COVID-19: An overview. Journal of Chinese Medical Association, 217-220. https://doi.org/10.1097/JCMA.0000000000000270>Wu.

Zhang, W., Wang, Y., Yang, L., \& Wang, C. (2020). Suspending Classes Without Stopping Learning: China's Education Emergency Management Policy in the COVID-19 Outbreak. Journal of Risk and Financial Management, 13(3). https://doi.org/10.3390/jrfm13030055.

Zhonggen, Y. (2019). A Meta-Analysis of Use of Serious Games in Education over a Decade. International Journal of Computer Games Technology, 19(3), 4. https://doi.org/10.1155/2019/4797032. 